\title{
IN THE SHADOW OF THE ASYLUM: THE STANLEY ROYD SALMONELLA OUTBREAK OF 1984
}

\section{Dr Jennifer Wallis}

\begin{abstract}
In August 1984, an outbreak of Salmonella at Stanley Royd psychiatric hospital in Yorkshire led to the deaths of nineteen elderly residents. It was an incident that attracted a good deal of comment in both the local and national press, and one that had enduring relevance for ideas about psychiatric care, food-handling and catering provisions, hospital management, and the official inspection of medical institutions. This article examines the impact that the 1984 outbreak had on official and popular perceptions of these issues. As well as bringing to public attention the fact that large numbers of vulnerable elderly patients were long-term residents in psychiatric hospitals, the Salmonella outbreak highlighted the inadequacies of Victorian hospital buildings in modern healthcare. Throughout the press reports and official investigations examined here, the provenance of Stanley Royd was repeatedly emphasised; its Victorian fabric persistently interfered with cleaning regimes, cold storage facilities, and the conveyance of food to patients. Within institutions like Stanley Royd, 'new' and 'old' risks came together - the microscopic bacterium and the crumbling nineteenth-century building - to create a strong critique of existing psychiatric care. The episode also highlighted broader problems within the NHS, such as systems of management and the status of psychogeriatrics as a specialism.
\end{abstract}




\section{IN THE SHADOW OF THE ASYLUM: THE STANLEY ROYD SALMONELLA OUTBREAK OF 1984}

Stanley Royd was an 850-bed psychiatric hospital on the outskirts of Wakefield in West Yorkshire. On Sunday $26^{\text {th }}$ August 1984, during the Bank Holiday weekend, a number of patients began to fall ill with diarrhoea. This wasn't that unusual, with a number of patients suffering from diarrhoea at any one time. What was unusual was the speed with which the symptoms spread: by 9.15 am, 36 patients across eight different wards had fallen ill. At $11.35 \mathrm{pm}$ the first fatality occurred. Being a Bank Holiday weekend, many doctors were away on holiday and, with staffing levels already low, the task of providing initial care fell to a recently-qualified junior doctor. On Bank Holiday Monday, a Cross-Infection Committee meeting was held, by which point it became clear that several nursing staff were also affected. The following day, Wakefield Health Authority's District Medical Officer attended another meeting of the Cross-Infection Committee. Later that day the Environmental Health Department were contacted and subsequently despatched one of their officers to the hospital. By that point, 240 patients were affected, and the outbreak was identified as Salmonella a bacterial infection of the digestive tract commonly spread via animal products such as meat and eggs. Outpatient and day attendance at the hospital was stopped, and an enquiry by Wakefield Health Authority begun. Initially, the cause of the outbreak was thought to be frozen carrots that had been cross-contaminated, but eventually cold roast beef used in salads was found to be the culprit. It was alleged that the beef had been cooked, cooled, and sliced onto plates which were then left in the open for 10 hours before being served to patients.

The hospital resumed normal operations in October, having undertaken a 'deep clean' of the kitchens, but both the scale and handling of the outbreak meant that it was not quickly forgotten. Nineteen patients, all of them over 65, had died. The number of deaths at Stanley Royd was the largest to occur in a single Salmonella incident. Though atypical, it was a key event informing the formation of the committee of parliamentary inquiry that presented the Acheson Report in 1988, a document that was perhaps the most thorough overview of the UK public health system since the nineteenth century. The outbreak at Stanley Royd had a significant impact on perceptions of hospital catering, staff supervision and management, and the organisation of psychiatric care in Britain more generally.

This article aims to address three key issues surrounding the 1984 incident. Firstly, what were the main points of criticism that came out in both official investigation into and media coverage of the outbreak? These centred around a previous instance of Salmonella at the hospital and inaction by 
local officials, but also raised the broader issue of how hospital catering services were inspected, as well as inefficient management across sections of the NHS. Secondly, how were the demographic characteristics of the victims important to the discussion, namely the elderly psychiatric patient as a vulnerable individual? A final point of consideration is how the patients themselves were eclipsed by something much larger: the physical fabric of the psychiatric hospital. Here, broader concerns about psychiatric services were added to 'horror stories' from the food poisoning outbreak, raising questions about the suitability of the psychiatric hospital for the elderly patient.

\section{Safety and secrecy}

Food safety was increasingly on the agenda around the time of the Stanley Royd Salmonella outbreak. In the 1970s rising reports of food poisoning were attributed to - amongst other things the growing popularity of convenience foods and increased poultry consumption. The Communicable Disease Surveillance Centre, set up in 1977, had food poisoning within its 'communicable disease' remit. The hazards of large-scale catering were investigated by the Food Hygiene Laboratory, who experimented on such matters as the defrosting of large turkeys, which had been implicated in many instances of food poisoning. Also in 1977, the identification of Campylobacter - another bacteria causing intestinal illness - encouraged doctors to keep a careful eye on possible food poisoning cases. Despite developments like these, though, food poisoning remained a relatively low priority for the government. In a 1976 publication on 'Prevention and Health' from the Department of Health and Social Security (DHSS), there was little mention of issues such as microbiological food safety. By the 1980s, what some commentators refer to as the 'new food movement' was gaining ground, with non-governmental organisations critiquing current food policy and campaigning for improvements. Food was also escaping the realms of Sunday supplements or so-called 'women's pages' with the formation of the Guild of Food Writers, who often supported new food movement campaigns.[1]

The Stanley Royd incident occurred, then, in a climate increasingly concerned with food safety and hygiene. A previous - albeit less severe - Salmonella outbreak at the hospital in 1979 had led to an investigation that described the kitchens as a 'culinary disaster area'.[2] Despite this, little was done as local officials debated how best to restructure the kitchens. A sum of $£ 5,000$ was allocated for a cold room or refurbishment of the walk-in refrigerator, but this money was not used for either purpose.[3] Assurances that improvements would be made appeared to be taken at face value, with little practical change forthcoming. As Lord Winstanley put it during a House of Lords debate: '[T]he 
Environmental Health Officer for Wakefield had warned the Stanley Royd Hospital over and over again regarding the deficiencies in hygiene practices and standards within the hospital. But no action was taken at all save the action taken by the bacterium [in the 1984 outbreak].'[4] Frank Dobson, MP for Holborn and St Pancras, was more direct: 'For over three years people argued and did what can only be described as sod-all - if it is in order to use that phrase.'[5]

This picture of arguments between departments and council officials was replicated in the 1984 outbreak, and made explicit in contemporary news reports. Judith Petts et al, discussing the role of media in risk perception, identify a tendency to seek the causes of risk events in the action or inaction of named individuals.[6] The failure of officials to carry out the tasks allotted to them is also discussed in William Freudenburg's analysis of what he calls 'mundane' risks such as BSE, where the actions of those we are unable to monitor or control come under scrutiny.[7] In the aftermath of the outbreak in Wakefield, Sir Jack Smart, Chairman of the Wakefield Health Authority, was just such an individual. As head of the Authority's enquiry into the outbreak, he denied the statements of nursing staff who had been quoted in the local paper about staff shortages, and conducted his investigations - as the Wakefield Express put it - under 'a shroud of secrecy'.[8] At a press conference he promised that members of the enquiry team would be available afterwards to answer questions, but reversed his decision 15 minutes later.[9] Accusations and counter-accusations flew between medical officials and union representatives for the kitchen staff, who passionately refuted the District Medical Officer's conclusion that the beef had been left unrefrigerated for 10 hours. Local headlines such as “Tight lips' over food poisoning' and 'Press requests to see kitchen refused' did little to counter the impression that something of a cover-up was being perpetuated by Smart and his colleagues. $[8,10]$

Compensating for official silence on the matter were accounts from current and previous hospital staff. Their statements highlighted the apparently woefully inadequate state of catering facilities that were not subject to regular official inspection: stories of 'contaminated beef ... served to patients, mouldering vegetables ... in the kitchen, liver with fluke ... in the catering department, kitchens ... [infested] with cockroaches, [and] dirty drains'.[11] In Britain at this time, hospital kitchens occupied a rather odd position, being exempt from inspection by environmental health officers due to 'crown immunity'. This was a provision dating back to 1889 and the beginning of the system of notifying infectious diseases; the system did not, however, apply to any building belonging to Her Majesty the Queen, or to any inmates within these buildings. Stanley Royd fell under this definition. Crown immunity was already being called into question before the outbreak occurred, but as the Stanley Royd incident came to light, the issue was given renewed impetus. A 1985 
environmental health report stated that 97 hospital kitchens across England and Wales would have been closed had they not enjoyed crown immunity.[12] This was a bizarre situation considering the increasing interest in food safety that had been gathering weight since the 1970s, but one that in many cases came down to the difficulty of putting theory into practice. Removing crown immunity raised a whole host of issues, including what was to be done for patients should a kitchen be found unsatisfactory and need to be immediately closed.

As Hugh Pennington has noted, although a 'virtually universal consensus' may have existed about the cooking time and temperature needed to kill bacteria, achieving consensus about 'how to ensure [such methods were] implemented in food businesses' (and in large institutions like Stanley Royd) was much more difficult.[13] During the parliamentary Inquiry into the 1984 outbreak (Committee of Inquiry into an Outbreak of Food Poisoning at Stanley Royd Hospital), a previous incident came to light that suggested all was not well in the hospital kitchen. In 1982 minced meat had been sent back to the kitchen from the wards as unsatisfactory and, on examination, found to contain significant levels of food poisoning bacteria. This prompted a staff memo reiterating the need for adherence to food storage and preparation guidelines, the last sentence of which had a 'grim prescience', warning staff that 'next time we may not be so lucky'.[14] The Inquiry's report frequently noted this failure to adhere to correct food handling, preparation, and cleaning procedures. A startling example was the practice of kitchen tables being cleaned and then wiped off with the same squeegees that were used on the floors.[15] Staff 'sampled' food, ate in the kitchen after managers had left at $5.00 \mathrm{pm}$, and altered menus when managers were absent at weekends.[16] It was not necessarily a lack of training that was the issue as the basics of food hygiene were known to staff, but rather 'the long standing failure of the supervisory grades to supervise adequately'.[17] Managers who left the premises at $5.00 \mathrm{pm}$ and who were nowhere to be found at weekends were hardly in a position to ensure that staff routinely complied with food safety guidelines.

In this sense, the Stanley Royd outbreak highlighted more than simply bad food handling practices, illustrating contemporary concerns about management within the NHS. The Griffiths Report of 1983 had strongly emphasised the need for effective management within the health service, advocating a system that would '[push responsibility] as far down the line as possible, i.e. to the point where action [could] be taken effectively'.[18] Though the Griffiths report was not a panacea for the NHS's ills (it seemed peculiarly unsuited to public health, for example, a field heavily reliant on collective action),[19] in 1984 Stanley Royd 'tragically illustrated' Griffiths' case: a lack of hands-on management in an overstretched system.[20] The Committee of Inquiry found it 'extraordinary' that, 
after 27 August, no clinical doctor in the hospital attended meetings of the Infectious Diseases Committee, and observed that the prevailing view of management seemed to be that it was 'best performed by standing back from the hurly burly'.[21]

There was a need for more rigorous inspection to check the unsatisfactory supervision of staff and oversights in health and safety matters. The kitchen had been informally visited by Wakefield's environmental health officers since the Authority was created in 1974, but the last visit made before the outbreak must have been cursory at best as the officer in question visited five hospitals (including Stanley Royd) in just four and a half hours.[22] The hospital, too, was not performing its food hygiene duties properly, failing to keep samples of all food served or not keeping these for a sufficient length of time.[23] Just as insider accounts and official reports highlighted the shortsightedness of crown immunity and the shortcomings of management and inspection systems, though, they also highlighted more tangible, day-to-day inadequacies - not least the challenges that staff faced in caring for elderly psychiatric patients.

\section{Uncovering a twilight world}

By the time of the Stanley Royd outbreak increasing attention was being paid to old-age psychiatry, or 'psychogeriatrics', a specialism that had developed slowly and sporadically in Britain throughout the second half of the twentieth century. The first old-age psychiatrist, Felix Post, had been appointed in 1947 but it was not until 1989 that psychogeriatrics was recognised as a specialty by the Department of Health. Although Enoch Powell's 'water tower speech' of 1961 had mentioned the need to carefully consider elderly patients in the move to community care, there remained a tendency in this area to focus on the young - a trend also evident in the anti-psychiatry movement.[24] Throughout the late 1960s and 1970s, new initiatives in old-age psychiatry tended to come from small groups of enthusiasts from a variety of backgrounds, such as those behind the DHSS's Services for Mental IIIness related to Old Age (1972).[25] Though the DHSS was concerned with providing adequate services for the elderly, this social work-oriented focus often meant that older mentally ill patients were overlooked by psychiatric services or 'misplaced' in hospitals as the physical and mental changes of ageing were conflated.[26, 27] Brice Pitt, writing in 1974, observed that the over 65s were disproportionately represented in psychiatric hospitals, with many long-term patients who had been there for several years. 'It is this group, increasing all the time', he said, 'which taxes the hospital most. Far less able to care for themselves than any other class of patients, they tax nursing resources while offering no prospect of their discharge or even improvement'.[28] 
Pitt expressed particular concern that, with the rise of community care, the most able nurses would choose to work in new outpatient settings rather than the inpatient hospital. Psychogeriatrics was not a popular specialty for nurses, received little money, and was often located in outdated buildings. In consequence, psychiatric and geriatric wards tended to be those hit hardest by staffing shortages.

Staff shortages were particularly problematic when one considered the extra issues to be taken into account when dealing with elderly psychiatric patients. The psychiatric hospital population was far from a homogenous one, and caring for the elderly brought with it a whole host of considerations and precautions. As well as their physical frailty, many patients became upset or intensely confused by changes to schedules, required special diets, or merited extra attention with regard to their bodily hygiene. An anonymous worker at Stanley Royd, speaking to The Observer during the outbreak, said that:

'The hospital runs on a bare minimum of staff at the best of times. A 30-bed geriatric ward of highly dependent elderly people is commonly staffed by two or three nurses, of whom only one may be qualified.'[29]

During the outbreak, these staffing issues made an already difficult situation even more challenging. Stanley Royd also suffered from a lack of clerical assistance at weekends, making simple tasks such as photocopying notices about food handling procedures difficult, and it had no night portering service - a deficiency with serious implications for the removal of soiled linen.[30] In an institution that many patients considered their home, it proved almost impossible to observe barrier nursing guidelines, as patients wandered from their beds, and shared cigarettes and drinking vessels. Complaining of the lack of emergency stock to carry out barrier nursing methods, Patricia Wilson, branch secretary of the Confederation of Health Service Employees (COHSE), reported that there were 'no overshoes, a lack of rubber gloves ... and washing bowls had to be used as vomit bowls'.[31] In an ideal situation staff would have changed their gowns to deal with each patient, but this was not possible, with only two barrier gowns apparently available across 10 wards. One nurse told the Confederation that 'she had to cut the neck out of a shroud and use that as a protective gown' (she was likely referring to the 200 sleeveless gowns obtained from the pathology laboratory).[32, 33] 
The Stanley Royd outbreak attracted both local and national press coverage, much of it expressing sympathy for the patients and a distinct sense of embarrassment that many of the country's psychiatric hospitals were filled with elderly people receiving inadequate nursing attention. This echoed earlier concerns for conditions within psychiatric institutions. In 1967 the Ely Hospital scandal prompted public outrage, and in the same year Aid for the Elderly in Government Institutions (AEGIS) presented a damning account of the treatment of the elderly in both mental and general hospitals.[34] Although the community hospitals of the 1970s had been touted as a solution to many of the problems of older institutions, plans for these had come to little and the elderly had continued to accumulate in mental hospitals.[35] At Stanley Royd, over half of the $c .830$ patients resident there in 1984 were over 64, and over a quarter of the hospital's total patients had been in the hospital for over 29 years. [36] An editorial in the Yorkshire Post mused: 'One consequence of an epidemic of these proportions is that it opens a window into a world which most people prefer to forget about. ... [These are patients] who have long since been abandoned by their families ... this is a twilight world'.[37] The victims of the outbreak, as one ex-nurse wrote to the Yorkshire Post, 'appear[ed] to have been dismissed ... as elderly and senile'.[38] There was concern and surprise that 'men and women over the age of 65 [were] still [being] admitted to psychiatric hospitals'.[39] Individual stories put a human face to the outbreak; in 1986 a profile of one patient appeared in a television series screened by Central Independent TV.[40] Such concern for the treatment of vulnerable individuals in institutions was not new, but the outbreak at Stanley Royd and the stories of its residents vividly illustrated the complexity of healthcare in Britain, bringing to light the overlap (or, rather, lack of overlap) between psychogeriatrics, public health, and physical sites of care. Indeed, the site of care was crucial: throughout discussions of the outbreak, apart from the individual patients, a central character in the drama was the hospital building itself.

\section{Victorian threats and modern risks}

Ulrich Beck, in Risk Society (1986), contrasted the hidden risks of modern life - invisible bacteria in food, for example - with the explicit risks of earlier periods such as the open sewer.[41] In the Stanley Royd episode, old and new risks came together. Invisible bacteria may have caused the deaths of 19 patients, but its action was aided by an ailing Victorian building. Although it might be argued that the outbreak 'could have happened in a number of places',[42] the incident illustrates how the politics of risk frequently coincide with the politics of space. Stanley Royd Hospital was viewed as a space with its own peculiar set of risks, both before and after the Salmonella outbreak. The building had served as a psychiatric hospital for its entire life, originally the West Riding Pauper 
Lunatic Asylum, which had opened its doors in 1818. Throughout the institution's history, the challenge of controlling infection had been a recurring issue. A Superintendent's report of 1880 linked an outbreak of diarrhoea amongst the older patients to inadequate drainage,[43] but later progress also brought its problems: as the hospital expanded, the 'building-on' of extra wings and rooms had transformed the site into a veritable rabbit warren by the late twentieth century.

In her recent study of the history of Salmonella, Anne Hardy emphasises how ideas about environmental pollution have been central to Salmonella prevention efforts, with particular sites (such as machines and worktops) singled out for attention.[44] As the heart of the 1984 incident, Stanley Royd's kitchens were the main site of concern. While the official enquiry into the outbreak highlighted the 'unhygienic and unsatisfactory practices [that] had grown up in the ... kitchen' [45] (discussed above), this criticism was qualified by recognition that working conditions were far from adequate. In a 1988 parliamentary debate on hospital domestic services, Stanley Royd was cited as an example in which 'conditions in the kitchen ... had nothing to do with the staff. The appalling fact was that they were working in an old workhouse building'.[46] This word 'workhouse' is one that came up more than once when Stanley Royd was being discussed, despite the fact that the building was never a workhouse. Nevertheless, it served to highlight the building's provenance and the outdated nature of its facilities. The hospital kitchens, dating back to the $1860 \mathrm{~s}$, were described as 'Dickensian',[47] with high ceilings that were almost impossible to clean and a shortage of adequate cold storage space meaning that meat was sometimes left to cool in corridors.[48] The 'long store' was a brick tunnel within which a temperature of $29^{\circ} \mathrm{C}$ was recorded by environmental health officers, the tiled floor of the main kitchen was cracked in places, and open drainage channels ran through the kitchen area.[49] Compounding the problem, the kitchens were some distance away from the wards; when meals arrived, they were re-heated before being served to patients. The risks posed by food, then, intersected with or highlighted, the risks posed by the space within which it circulated.

The large scale of the hospital complex was often emphasised in images accompanying press reports. Spots on local TV news typically opened with a sweeping shot that drew back to take in the imposing brick building that formed the original and oldest part of the hospital.[50] Several newspaper reports accompanied their stories with an aerial photograph to emphasise the scale of the site. One added an arrow to indicate the kitchen block at the heart of the old Victorian building, illustrating both the size of the hospital and the distance to be travelled from the kitchen to the outer wards.[8] There were no isolation facilities available during the outbreak (though there had 
been plans to adapt the hospital's Hazel Ward for this purpose),[51] so patients were either transferred to nearby Seacroft Hospital or collected together, mixed sex, in one of the existing male wards, a situation causing many patients further distress. In a parliamentary debate, one MP's comment made clear that the building's history loomed large in discussions of its present situation: 'To help the House get this hospital into perspective, will the Secretary of State confirm that it was built ... when Napoleon was alive and that it was called the West Riding paupers [sic] lunatic asylum?'[2]

Stanley Royd was not the only example of a Victorian asylum that had been maintained as a psychiatric hospital, of course, and contemporary commentators emphasised that the hospital's problems were symptomatic of many other psychiatric units. A newspaper article announcing that Stanley Royd was re-opening after its deep clean in October added that nine patients were currently suffering from food poisoning at Rainhill Hospital on Merseyside.[52] That this was an ongoing problem was highlighted in a 1989 study of Salmonella that found the psychiatric hospital to be the type of hospital most prone to food-borne outbreaks, due to the tendency to feed many patients out of a central kitchen.[53] The issue of crown immunity was irrelevant, then, if psychiatric patients were being housed and attended to in buildings that were not fit for purpose in the first place.

\section{Aftermath}

Stanley Royd closed in 1995. The 1984 outbreak had served as an 'epidemiological lesson', [54] highlighting the need for more rigorous inspection of institution's catering practices and careful consideration of their public health responsibilities. A few years after the Stanley Royd outbreak the dangers of food for the general public - not just the hospital patient - came to the fore with the Salmonella in eggs scandal and the BSE crisis. The late 1980s was a period when more government attention began to be turned towards the issue of microbiological food safety, with the London Food Commission founded in 1985 and the Food Safety Act of 1990 tightening food-handling provisions. In the early 1990s crown immunity was finally removed, with some exceptions for national security reasons.

Microbiological food safety was rarely discussed in the local news reports covering Stanley Royd. Initially there were several rumours about the source of the outbreak - including vague mentions of 'a cat' and tales of a maggot-infested tin of discarded school dinners found nearby.[50,55] Local headlines portrayed the whole incident as something of a mystery: 'Hospital food poison puzzle', 
'Hospital deaths riddle', 'Mystery of the kitchen killer'.[56-58] When scientific evidence was forthcoming, it was sometimes refuted by staff. Geoffrey Ireland, heading the biological investigation, was confident that the meat in question had been left in the open from 7.15 am until 5.00 pm, but members of the National Union of Public Employees (NUPE) disagreed, arguing it had only been left out for just over two hours.[59] As Timothy Cooper and Sarah Bulmer have found in regard to interwar tipping, even in the later twentieth century laboratory science did not necessarily lead to consensus or resolve a problem.[60] Such disagreements were not aided by the culture that seemed to prevail at Stanley Royd, in which ward and kitchen staff rarely came into meaningful contact with managers, and staff with supervisory responsibilities were frequently absent or unavailable. The lack of co-operation with officials outside the hospital, too, was clearly a matter that merited serious attention. Despite the presence of an elderly and vulnerable population in a building that had harboured a previous Salmonella outbreak, it seemed that little in the way of risk prevention was taking place there. After the Committee of Inquiry had presented its report, Wakefield Health Authority instituted a system of cook-chill catering - in which food is pre-prepared and put into oven-ready containers for heating. It was noted that this move hadn't been discussed with an infection officer or microbiologist, and was roundly condemned as an inadequate fix for a much larger problem.[61]

The Stanley Royd outbreak occurred at a time when public health had slipped somewhat from the agenda: the reorganisation of the NHS in the 1970s led to the abolition of the office of Medical Officer of Health in 1973-74 and the rise of 'community physicians', a change that led to a degree of demoralization amongst public health workers.[62] Arguments in favour of a comprehensive, properly networked, system of public health surveillance were lent weight by Stanley Royd. The 1986 Committee of Inquiry, responding to the DHSS review of the Public Health Laboratory Service (PHLS) taking place at the time of their investigation, expressed their reservations about any decentralisation of the body: as senior Medical Officers of Health retired from service, they said, community physicians would be less able to compensate for their expertise in matters of public health and infection. This was all the more serious when one considered the 'resistance to seeking assistance from any outside authority' that the Committee had identified during its enquiries at Wakefield.[63] Alongside other developments - the 1985 outbreak of Legionnaire's disease at Stafford, the identification of BSE in 1986, and the rise of HIV/AIDS - the lessons of Stanley Royd could be glimpsed in the Acheson Report of 1988. The Report's emphasis on collaboration, partnership, and the role of society as a whole in improving health pinpointed precisely those qualities that seemed to be lacking in 1984: co-operation with outside agencies, the working 
together of staff and managers, and broader societal concern for the fate of the elderly within the welfare system.

Throughout the Committee of Inquiry report, one finds praise for the day-to-day staff of the hospital - long-term employees who provided guidance in the absence of managerial direction and nurses who made 'remarkable efforts' in 'atrocious' conditions.[64] It was emphasised that these efforts took place in spite of poor management, but also in spite of something more intractable.[65] The outbreak had strengthened ideas of the psychiatric hospital as a site of special risk, and called into question existing arrangements of psychiatric care. In the 1960s, when community care began to be seriously pursued, there were calls for the elderly to be the first to be reintegrated into communities. This occurred in isolated instances, but Stanley Royd seemed to embody the fears expressed by Tony Whitehead in 1983, of large mental hospitals turning into 'depositories for the elderly'.[66] Although the 1986 Committee noted that Stanley Royd was expected to remain as a mental hospital for the 'foreseeable future',[67] the accident of a large-scale Salmonella outbreak provided the perfect illustration of how the nineteenth-century asylum building was unsuited to modern care, with the structure and its residents reflecting wider problems in the NHS. The lack of meaningful dialogue between social, psychiatric, and general hospital services - and a dearth of alternative provision for the elderly - meant that too many patients found themselves cast into the 'dumping ground' of an old asylum where conditions seemed uncomfortably evocative of the building's Victorian past. This concern for the site itself was especially evident in press reports surrounding the outbreak, where one found not only 'hard facts' about bacteria and nursing provision, but a more general and less easily definable unease about the history of institutions like Stanley Royd, with the hospital's nineteenth-century origins starkly at odds with modern practice ideals. The physical fabric of the building, then, was an obstacle that could not be overcome simply by instituting modern catering methods or new systems of management.

\section{Acknowledgements}

I would like to thank Anne Hardy and Keir Waddington for their encouragement to publish this research as an article, and the two anonymous reviewers for their helpful and insightful comments.

\section{References}

1. Lang T. Going public: Food campaigns during the 1980s and early 1990s. In: Smith DF, ed. Nutrition in Britain: Science, Scientists and Politics in the Twentieth Century. Abingdon, Oxon: Routledge 2013:238-60. 
2. HC Deb 21 January 1986 vol. 90 cols 190-202.

3. Great Britain Committee of Inquiry into an Outbreak of Food Poisoning at Stanley Royd Hospital. The Report of the Committee of Inquiry into an Outbreak of Food Poisoning at Stanley Royd Hospital. London: HMSO 1986:61.

4. HL Deb 21 January 1986 vol. 470 cols $134-43$.

5. HC Deb 9 June 1986 vol. 99 cols $98-131$.

6. Petts J, Horlick-Jones T, Murdock G. Social Amplification of Risk: The Media and the Public. Sudbury: HSE Books 2001.

7. Freudenburg WR. Institutional failure and the organizational amplification of risks: the need for a closer look. In: Pidgeon N, Kasperson RE, Slovic P, eds. The Social Amplification of Risk. Cambridge: CUP 2003:102-20.

8. Walters L. 'Tight lips' over food poisoning. Wakefield Express 14 Sept. 1984.

9. Mitchell S. Meat that came out of the cold. Yorkshire Post 11 Sept. 1984.

10. Anon. Press requests to see kitchen refused. Wakefield Express 14 Sept. 1984.

11. HC Deb 15 April 1986 vol. 95 cols 795-825.

12. Connett D. Scandal of the 97 dirty hospitals. The Sunday Times 22 Sept. 1985.

13. Pennington $\mathrm{H}$. Recent experiences in food poisoning: science and policy, science and the media. In: Smith DF, Phillips J, eds. Food, Science, Policy and Regulation in the Twentieth Century: International and Comparative Perspectives. London: Routledge 2000:229.

14. Report of the Committee of Inquiry:8-9.

15. Report of the Committee of Inquiry: 64 .

16. Report of the Committee of Inquiry:63, 70.

17. Report of the Committee of Inquiry: 106.

18. Griffiths R. NHS Management Inquiry. London: HMSO 1983. http://www.sochealth.co.uk/national-health-service/griffiths-report-october-1983/ Last accessed 19 May 2015.

19. Berridge V, Christie DA, Tansey EM, eds. Public health in the 1980s and 1990s, decline and rise? The transcript of a Witness Seminar held by the Wellcome Trust Centre for the History of Medicine at UCL, London, on $12^{\text {th }}$ October 2004. London: Wellcome Trust Centre for the History of Medicine at UCL 2006:24.

20. Fowler N. Ministers Decide. A Personal Memoir of the Thatcher Years. London: Chapmans 1991:195.

21. Report of the Committee of Inquiry:35, 41.

22. Report of the Committee of Inquiry:76. 
23. Report of the Committee of Inquiry:15.

24. Hilton C. 'Sans teeth, sans eyes, sans taste, sans everything': resourcing mental health services for older people. Journal of the Royal Society of Medicine 2012; 105:146.

25. Hilton C. The clinical psychiatry of late life in Britain from 1950 to 1970: an overview. International Journal of Geriatric Psychiatry 2005; 20:427.

26. Hilton C. The provision of mental health services in England for people over 65 years of age, 1970-78. History of Psychiatry 2008; 19:312.

27. Kidd CB. Misplacement of the elderly in hospital: a study of patients admitted to geriatric and mental hospitals. BMJ 1962; 5318.

28. Pitt B. Psychogeriatrics: An Introduction to the Psychiatry of Old Age. Edinburgh: Churchill Livingstone 1974:155.

29. Nally M. Staff blame cuts for hospital toll. The Observer 9 Sept. 1984.

30. Report of the Committee of Inquiry:48.

31. Anon. Demand for public probe into hospital epidemic. Wakefield Express 7 Sept. 1984.

32. Anon. Union inquiry into Stanley Royd outbreak hits hard. Hemsworth and South Elmsall Express 25 Oct. 1984.

33. Report of the Committee of Inquiry:19.

34. Robb B. Sans Everything: A Case to Answer. London: Nelson 1967.

35. Hilton, Provision:311.

36. Report of the Committee of Inquiry:4.

37. Anon. Hospital hazards. Yorkshire Post 7 Sept. 1984.

38. Donkin R. Ex-nurse tells of wards vermin. Yorkshire Post 12 Sept. 1984.

39. Chetwood R. Inquiry need into outbreak at hospital. Wakefield Express 14 Sept. 1984.

40. 'Bound to back a winner' episode of Getting On. Central Independent TV. 12 Jan. 1986. Cited in: Anon. Victim's story on TV. Wakefield Express 10 Jan. 1986.

41. Beck U. Risk Society: Towards a New Modernity. Trans. Ritter M. London: Sage Publications 1992 (1986).

42. Berridge et al, Public health:9.

43. West Yorkshire Archive Service, Wakefield. Stanley Royd Hospital. C85/1/13/3 Medical Director's journal 1874-1881: Annual meeting, 29 Jan. 1880.

44. Hardy A. Salmonella Infections, Networks of Knowledge, and Public Health in Britain, 18801975. Oxford: OUP 2015:7.

45. HL Deb 21 January 1986 vol. 470 cols 134-43.

46. HC Deb 13 April 1988 vol. 131 cols 271-89. 
47. Pennington H. When Food Kills: BSE, E. Coli, and Disaster Science. Oxford: Oxford University Press 2003:54.

48. Parkin M. Poisoning at hospital 'was caused by poultry'. The Guardian 27 Feb. 1985.

49. Report of the Committee of Inquiry:60-61.

50. Food Poisoning at Stanley Royd Hospital. ITN 7 Sept. 1984. http://jiscmediahub.ac.uk/record/display/024-JISC_127513_01. Last accessed 5 Oct. 2014.

51. Report of the Committee of Inquiry:19.

52. Anon. Salmonella-hit hospital to re-open. Yorkshire Post 2 Oct. 1984.

53. Joseph CA, Palmer SR. Outbreaks of salmonella infection in hospitals in England and Wales 1978-87. BMJ 1989; 298:1161-64.

54. Anon. Stanley Royd: the epidemiological lesson. BMJ 1986; 292:644-45.

55. Anon. Salmonella hospital: five more taken ill. Yorkshire Post 13 Sept. 1984.

56. Anon. Hospital food poison puzzle. Yorkshire Post 30 Aug. 1984.

57. Anon. Hospital deaths riddle. Yorkshire Post 1 Sept. 1984.

58. Anon. Mystery of the kitchen killer. Yorkshire Post 7 Sept. 1984.

59. Anon. No decision yet on public inquiry. Wakefield Express 14 Sept. 1984.

60. Cooper T, Bulmer S. Refuse and the 'risk society': the political ecology of risk in inter-war Britain. Social History of Medicine 2013; 26:246-66.

61. HC Deb 26 November 1987 vol. 123 cols 397-480.

62. Berridge et al, Public health:xxi.

63. Report of the Committee of Inquiry:37.

64. Report of the Committee of Inquiry:80, 24.

65. Report of the Committee of Inquiry:69.

66. Whitehead T. Closing large mental hospitals. The Lancet 1983; 8359:1140.

67. Report of the Committee of Inquiry:97. 